\title{
Long-term immunological responses to treatment among HIV-2 patients in Côte d'Ivoire
}

Peter A. Minchella ${ }^{*^{*}}$ DD, Christiane Adjé-Touré ${ }^{2}$, Guoqing Zhang ${ }^{1}$, Andre Tehe ${ }^{2}$, Judith Hedje ${ }^{2}$, Erin R. Rottinghaus ${ }^{1}$, Natacha Kohemun², Micheline Aka², Karidia Diallo ${ }^{3}$, G. Laissa Ouedraogo ${ }^{2}$, Kevin M. De Cock ${ }^{4}$ and John N Nkengasong ${ }^{5}$

\begin{abstract}
Background: Studies indicate that responses to HIV-2 treatment regimens are worse than responses to HIV-1 regimens during the first 12 months of treatment, but longer-term treatment responses are poorly described. We utilized data from Côte d'Ivoire's RETRO-Cl laboratory to examine long-term responses to HIV-2 treatment.

Methods: Adult ( $\geq 15$ years) patients with baseline CD4 counts $<500$ cells/ $\mu$ l that initiated treatment at one of two HIV treatment centers in Abidjan, Côte d'Ivoire between 1998 and 2004 were included in this retrospective cohort study. Patients were stratified by baseline CD4 counts and survival analyses were employed to examine the relationship between HIV type and time to achieving CD4 $\geq 500$ cells/ $\mu$ l during follow up.

Results: Among 3487 patients, median follow-up time was 4 years and $57 \%$ had documented ART regimens for > $75 \%$ of their recorded visits. Kaplan-Meier estimates for achievement of CD4 $\geq 500$ cells/ul after 6 years of follow-up for patients in the lower CD4 strata (<200 cells/ $\mu$ l) were 40\% (HIV-1), 31\% (HIV-dual), and 17\% (HIV-2) (log-rank $p<$ 0.001). Cox Regression indicated that HIV-1 was significantly associated with achievement of CD4 $\geq 500$ cells/ $\mu \mathrm{l}$ during follow-up, compared to HIV-2.
\end{abstract}

Conclusions: Sub-optimal responses to long-term HIV-2 treatment underscore the need for more research into improved and/or new treatment options for patients with HIV-2. In many West African countries, effective treatment of both HIV-1 and HIV-2 will be essential in the effort to reach epidemic control.

Keywords: HIV, HIV-2, CD4, ART, Côte d'Ivoire, Africa

\section{Background}

The vast majority of individuals with HIV-2, including those dually reactive with HIV-1 and HIV-2 (HIV-D), are in West Africa, where the HIV-2 virus was first isolated in 1986 [1]. HIV-2 is generally considered to be less virulent than HIV-1; and HIV-2 infections typically have longer stages of clinical latency [2], slower CD4

\footnotetext{
* Correspondence: klf9@cdc.gov

'Division of Global HIV and Tuberculosis, Centers for Disease Control and Prevention, 1600 Clifton Rd., Atlanta, GA, USA

Full list of author information is available at the end of the article
}

depletion rates [3], and lower viral loads [4, 5]. Despite this, many patients with HIV-2 progress to AIDS [6], acquire opportunistic infections [7], and experience AIDSrelated mortality.

Historically, antiretroviral therapy (ART) guidelines for patients with HIV-2 have been based on 'low quality' evidence, such as observational studies, case reports, and in vitro studies $[8,9]$. Broadly, this evidence has shown that HIV-2 is resistant to non-nucleoside reverse transcriptase inhibitors (NNRTIs) [10], shows decreased susceptibility to some protease inhibitors (PIs) [11, 12], and

C C The Author(s). 2020 Open Access This article is licensed under a Creative Commons Attribution 4.0 International License, which permits use, sharing, adaptation, distribution and reproduction in any medium or format, as long as you give appropriate credit to the original author(s) and the source, provide a link to the Creative Commons licence, and indicate if changes were made. The images or other third party material in this article are included in the article's Creative Commons licence, unless indicated otherwise in a credit line to the material. If material is not included in the article's Creative Commons licence and your intended use is not permitted by statutory regulation or exceeds the permitted use, you will need to obtain permission directly from the copyright holder. To view a copy of this licence, visit http://creativecommons.org/licenses/by/4.0/ The Creative Commons Public Domain Dedication waiver (http://creativecommons.org/publicdomain/zero/1.0/) applies to the data made available in this article, unless otherwise stated in a credit line to the data. 
is susceptible to a variety of nucleoside reverse transcriptase inhibitors (NRTIs), boosted PIs, and integrase inhibitors [13]. Recent data indicate that the integrase strand transfer inhibitor (INSTI) class of integrase inhibitors are safe and effective against HIV-2 [14, 15]. While reports suggest that boosted PI-containing regimens perform better that triple NRTI regimens [16], it has been challenging to identify a preferred initial ART regimen for patients with HIV-2 [17] - which is reflected by comparatively poor responses to treatment among those patients. Specifically, reports indicate that both reduction in viral load [18] and CD4 recovery [19] are suboptimal for HIV-2 patients during the first 12 months of ART, compared to patients with HIV-1. Diminished CD4 recovery in patients with HIV-2 was even observed after adjustment for pretreatment plasma viral load [20], which some hypotheses credit as the cause of poor CD4 recovery.

While this evidence makes a strong case for development of improved treatment options for patients with HIV-2, there is a clear gap in the data when it comes to long-term responses to treatment. Only a few HIV-2 studies exceed 12 months of follow-up [21-23], limiting understanding of how responses to treatment evolve over time. We aimed to address this gap via a retrospective cohort study that assessed long-term CD4 recovery according to HIV type in Côte d'Ivoire, a West African country where 5\% of HIV-infected adults are estimated to have HIV-2 or HIV-D infection [24].

\section{Methods}

\section{Setting}

Starting in 1998, with support from the UNAIDS Drug Access Initiative (DAI), the Côte d'Ivoire Ministry of Health implemented a pilot ART program that was designed to serve as a model for providing ART in lowresource settings. Seven treatment centers in Abidjan, Côte d'Ivoire were accredited to provide ART to patients that met sociodemographic and biological eligibility criteria and all laboratory testing for specimens referred from those patients was conducted at the RETRO-CI laboratory, also in Abidjan [25].

Project RETRO-CI is a collaboration between the U.S Centers for Disease Control and Prevention (CDC) and the Ivorian Ministry of Health that provides laboratory testing and data management support to the clinics referring patient specimens to the RETRO-CI laboratory.

\section{Study design and population}

Adult ( $\geq 15$ years) patients with documented HIV types and baseline CD4 counts $<500$ cells $/ \mu$ l that initiated ART at one of two HIV treatment centers between 1998 and 2004 were included in this retrospective cohort study. The treatment centers, Unité de Soins
Ambulatoire et de Conseil (USAC) and Service de Maladies Infectieuses et Tropicales, were located at Treichville University Hospital (UTH) in Abidjan and accredited to provide ART as part of the initial DAI pilot. The remaining five treatment centers that were accredited as part of the DAI pilot were not included in this study. The baseline CD4 count was defined as that recorded as part of the bilan initial or 'initial visit' for each patient in the RETRO-CI database. Data on patient demographics and laboratory testing results were extracted from the RETRO-CI laboratory database. Data on treatment regimens were also extracted from the database, though only the presence/absence of initial treatment regimens were used, as details of specific regimens were not recorded with the intention of serving as a primary data source.

\section{Outcomes and exposure variables}

The primary outcome was achievement of $\mathrm{CD} 4 \geq 500$ cells/ $\mu$ l, which has been linked to a reduced risk of clinical progression for patients on ART [26]. Patients were categorized by HIV type and stratified by baseline CD4 counts. Patient demographics, baseline CD4 counts, and the ART clinic at which the patient initiated treatment were factors included in multivariable models.

\section{Data analysis}

Data were analyzed using SAS 9.4 (SAS Institute Inc., Cary, NC). The dataset utilized may be requested from the RETRO-CI laboratory and the Ivorian Ministry of Health.

Frequencies were generated for categorical variables and means, standard deviations, medians, and interquartile ranges (IQR) for normally distributed and nonnormally distributed continuous variables, respectively.

Survival analyses were employed to examine the relationship between HIV type and time to achieving CD $4 \geq$ 500 cells/ $\mu$ l during follow up in two baseline CD4 strata. Patients were censored if the study period closed prior to achievment of $\mathrm{CD} 4 \geq 500$ cells $/ \mu$ l. The end of the study period was July 31, 2015. Kaplan-Meier (KM) methods were used to estimate and visualize survival probabilities as a function of time and log-rank tests were utilized to compare KM curves across HIV types. Cox proportional hazards regression models were used to estimate crude and adjusted hazard ratios (HR and aHR) and 95\% confidence intervals (CI) for exposure variables. HIV-2 served as the reference category for all models.

\section{Results}

Demographics and characteristics for 3487 patients included in this study are summarized in Table 1. Overall, compared to their counterparts in the lower CD4 strata 
Table 1 Demographics and characteristics of study patients by baseline CD4 strata and HIV type

\begin{tabular}{|c|c|c|c|c|c|c|c|c|c|}
\hline & \multicolumn{4}{|c|}{ Baseline CD4 < 200 cells/ $\mu \mathrm{l}$} & \multicolumn{4}{|c|}{ Baseline CD4 200-500 cells/ $\mu \mathrm{l}$} & \\
\hline & $\mathrm{HIV}-1$ & HIV-2 & HIV-D & Total & HIV-1 & HIV-2 & HIV-D & Total & \\
\hline Total patients, $\mathrm{n}$ & 2165 & 77 & 108 & 2350 & 1049 & 31 & 57 & 1137 & 3487 \\
\hline Visits, median (IQR) & $7.0(3-19)$ & $7.0(3-16)$ & $7.0(3-17)$ & $7.0(3-19)$ & $8.0(3-18)$ & $11.0(3-21)$ & $7.5(3-18.5)$ & $8.0(3-18)$ & $7.0(3-19)$ \\
\hline $\begin{array}{l}\text { Follow-up time (years), median } \\
\text { (IQR) }\end{array}$ & $\begin{array}{l}3.8(0.7- \\
11.2)\end{array}$ & $\begin{array}{l}3.0(0.8- \\
8.0)\end{array}$ & $\begin{array}{l}2.5(0.7- \\
10.7)\end{array}$ & $\begin{array}{l}3.7(0.7- \\
11.2)\end{array}$ & $\begin{array}{l}4.5(1.0- \\
11.3)\end{array}$ & $\begin{array}{l}5.6(2.6- \\
10.6)\end{array}$ & $\begin{array}{l}4.7(1.4- \\
11.0)\end{array}$ & $\begin{array}{l}4.6(1.0- \\
11.3)\end{array}$ & $\begin{array}{l}4.0(0.8- \\
11.2)\end{array}$ \\
\hline \multicolumn{10}{|l|}{ Year of baseline CD4, n (\%) } \\
\hline $1998-2000$ & $444(20.5)$ & $15(19.5)$ & $29(26.9)$ & $488(20.8)$ & $254(24.2)$ & $8(25.8)$ & $11(19.3)$ & $273(24.0)$ & $761(21.8)$ \\
\hline $2001-2002$ & $768(35.5)$ & $31(40.3)$ & $40(37.0)$ & $839(35.7)$ & $394(37.6)$ & $10(32.3)$ & $27(47.4)$ & $431(37.9)$ & $1270(36.4)$ \\
\hline 2003-2004 & $953(44.0)$ & $31(40.3)$ & $39(36.1)$ & $1023(43.5)$ & $401(38.2)$ & $13(41.9)$ & $19(33.3)$ & $433(38.1)$ & $1456(41.8)$ \\
\hline $\begin{array}{l}\text { CD4 count (cells/ } \mu \mathrm{l}) \text {, median } \\
\text { (IQR) }\end{array}$ & $\begin{array}{l}69(21- \\
127)\end{array}$ & $\begin{array}{l}69(42- \\
112)\end{array}$ & $\begin{array}{l}71(23- \\
125)\end{array}$ & $\begin{array}{l}69(22- \\
126)\end{array}$ & $\begin{array}{l}299(246- \\
381)\end{array}$ & $\begin{array}{l}282(236- \\
373)\end{array}$ & $\begin{array}{l}312(250- \\
382)\end{array}$ & $\begin{array}{l}299(246- \\
381)\end{array}$ & $\begin{array}{l}128(41- \\
244)\end{array}$ \\
\hline \multicolumn{10}{|l|}{ Age (years) } \\
\hline Age, mean $\pm S D$ & $37.8 \pm 8.7$ & $43.8 \pm 8.3$ & $41.4 \pm 6.6$ & $38.2 \pm 8.7$ & $36.7 \pm 9.4$ & $41.3 \pm 9.3$ & $39.7 \pm 8.3$ & $37.0 \pm 9.4$ & $37.8 \pm 9.0$ \\
\hline$<35, \mathrm{n}(\%)$ & 837 (38.7) & $8(10.4)$ & 15 (13.9) & 860 (36.6) & $487(46.4)$ & $6(19.4)$ & $17(29.8)$ & $510(44.9)$ & $1370(39.3)$ \\
\hline $35-44, n(\%)$ & 844 (39.0) & 39 (50.6) & $57(52.8)$ & $940(40.0)$ & $358(34.1)$ & $11(35.5)$ & $28(49.1)$ & 397 (34.9) & 1337 (38.3) \\
\hline$\geq 45, \mathrm{n}(\%)$ & $484(22.4)$ & $30(39.0)$ & 36 (33.3) & $550(23.4)$ & $204(19.4)$ & $14(45.2)$ & $12(21.1)$ & $230(20.2)$ & $780(22.4)$ \\
\hline \multicolumn{10}{|l|}{ Sex, n (\%) } \\
\hline Female & 1107 (51.1) & $33(42.9)$ & 37 (34.3) & $1177(50.1)$ & $626(59.7)$ & $11(35.5)$ & $29(50.9)$ & $666(58.6)$ & $1843(52.9)$ \\
\hline Male & $1058(48.9)$ & $44(57.1)$ & $71(65.7)$ & $1173(49.9)$ & $423(40.3)$ & $20(64.5)$ & $28(49.1)$ & $471(41.4)$ & $1644(47.2)$ \\
\hline \multicolumn{10}{|c|}{ Percentage of visits with documented ART regimen, n (\%) } \\
\hline$<50 \%$ & $216(10.0)$ & $8(10.4)$ & $12(11.1)$ & $236(10.0)$ & $307(29.2)$ & $8(25.8)$ & $15(26.3)$ & $330(29.0)$ & $566(16.2)$ \\
\hline $50-75 \%$ & $614(28.3)$ & $26(33.7)$ & $31(28.7)$ & $671(28.6)$ & $229(21.8)$ & $6(19.4)$ & $17(29.8)$ & $252(22.2)$ & $923(26.5)$ \\
\hline$>75 \%$ & 1335 (61.7) & $43(55.8)$ & $65(60.1)$ & $1443(61.4)$ & $513(48.9)$ & $17(54.8)$ & $25(43.8)$ & $555(48.8)$ & $1998(57.3)$ \\
\hline
\end{tabular}

Values are reported as median (IQR), mean $\pm \mathrm{SD}$, or $\mathrm{n}(\%)$. Visits and follow-up time refer only to visits recorded in the RETRO-CI laboratory database - if visits did not include specimen referrals to RETRO-Cl they were not included. The percentage of visits with a documented ART regimen refers to visits in the RETRO-CI database (not including the initial visit) for which a current ART regimen was recorded

Abbreviations: IQR Interquartile range, SD Standard deviation, ART Antiretroviral therapy

$(<200$ cells/ $\mu \mathrm{l})$, patients in the upper CD4 strata $(200-$ 500 cells $/ \mu \mathrm{l}$ ) had longer median follow-up times, were younger, and were more likely to be female. Within-CD4 strata comparisons by HIV type revealed that HIV-2 and HIV-D patients were older and more likely to be male.

\section{Treatment}

Overall, nearly $80 \%$ of patients had documented ART regimens at the time of their initial visits (Table 2) and
$57 \%$ of patients had documented ART regimens for > $75 \%$ of their recorded visits (Table 1 ).

\section{Achievement of CD4 $\geq \mathbf{5 0 0}$ cells $/ \mu \mathrm{l}$}

For patients in the lower CD4 strata, KM estimates for achievement of CD4 $\geq 500$ cells/ $\mu$ l after 3 and 6 years were highest amongst those with HIV-1 (3 years $=15 \%$; 6 years $=40 \%)$, followed by HIV-D ( 3 years $=6 \%$; 6 year $=$ $31 \%)$ and HIV-2 (3 years $=2 \% ; 6$ years $=17 \%)($ log-rank $p<0.001$; Fig. 1). KM estimates for achievement of

Table 2 HIV type and association with achieving CD4 $\geq 500$ cells/ $\mu$ l during follow-up

\begin{tabular}{llllll}
\hline Baseline CD4 count & HIV type & Hazard Ratio (HR) & $95 \%$ Cl & Adjusted HR & $95 \%$ Cl \\
\hline$<200$ cells/ $\mu$ l & HIV-1 & 3.36 & $1.68-6.75$ & 2.60 & $1.29-5.22$ \\
& HIV-D & 2.11 & $0.94-4.74$ & 2.22 & $0.99-4.99$ \\
HIV-2 & - & - & - & - \\
& HIV-1 & 1.64 & $0.92-2.91$ & 1.42 & $0.79-2.55$ \\
& HIV-D & 1.47 & $0.74-2.92$ & 1.32 & - \\
& HIV-2 & - & - & - & $0.65-2.66$ \\
\end{tabular}




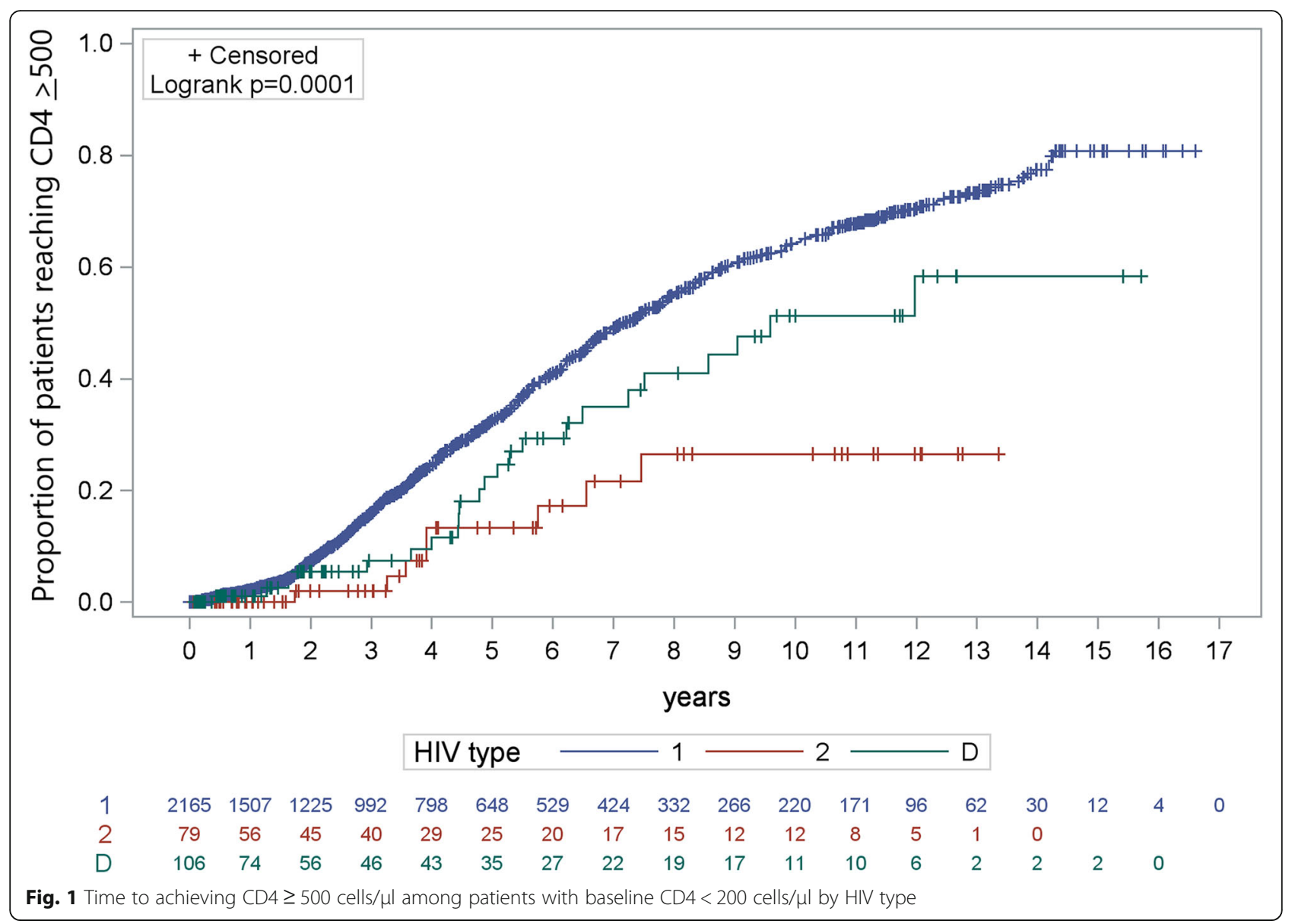

CD4 $\geq 500$ cells $/ \mu$ in the upper CD4 strata followed a similar trend $(\mathrm{HIV}-1,3$ years $=30 \%, 6$ years $=57 \%$; HIVD: 3 years $=23 \%$, 6 years $=54 \%$; HIV-2: 3 years $=20 \%, 6$ years $=42 \%$ ), though the KM curves were not significantly different (log-rank $p=0.33$; Fig. 2).

Factors associated with achievement of CD4 $\geq 500$ cells/ $\mu$ l Among 2350 patients in the lower CD4 strata HIV-1 was significantly associated with achieving CD4 $\geq 500$ cells/ $\mu \mathrm{l}$ during follow-up compared to HIV-2 (Table 2). HIV-D was also positively associated with achieving CD4 $\geq 500$ cells/ $\mu$ l during follow-up compared to HIV-2, but the associations were not significant. There was not a significant association between HIV type and achieving CD4 $\geq 500$ cells/ $\mu$ l during follow-up in the upper CD4 strata.

\section{Discussion}

Among a well-characterized cohort of HIV-infected patients with low baseline CD4 counts in Côte d'Ivoire, those with HIV-1 were more likely than those with HIV-2 to achieve CD4 $\geq 500$ cells/ $\mu$ l during follow-up. These results reinforce the importance of early ART initiation for all
HIV types and underscore the need for improved HIV-2 treatment options and HIV-2 treatment guidelines.

Historically, low prevalence and geographic restrictions limited HIV-2 studies to small sample sizes and short follow-up periods. This study was unique in that it included long follow-up periods for relatively large numbers of HIV-2 patients, demonstrating the utility of databases such as the one maintained at the RETRO-CI laboratory and providing an opportunity to assess responses to treatment over time. In that context, we found that immunological responses among patients with HIV-2 were suboptimal in a cohort of patients with low baseline CD4 counts and a median follow-up period of nearly 4 years.

While the mechanisms responsible for sub-optimal treatment responses are beyond the scope of this study, our results hint at some possible scenarios. The most notable are related to $\mathrm{CD} 4$ recovery plateaus and the relationship between baseline and peak CD4 counts, both of which have been described in responses to treatment among HIV-1 patients with suppressed viral loads [2729]. Specifically, since HIV-2 patients tend to present with lower viral loads $[4,5]$ following longer periods of clinical latency [2], CD4 recovery plateaus may be lower 


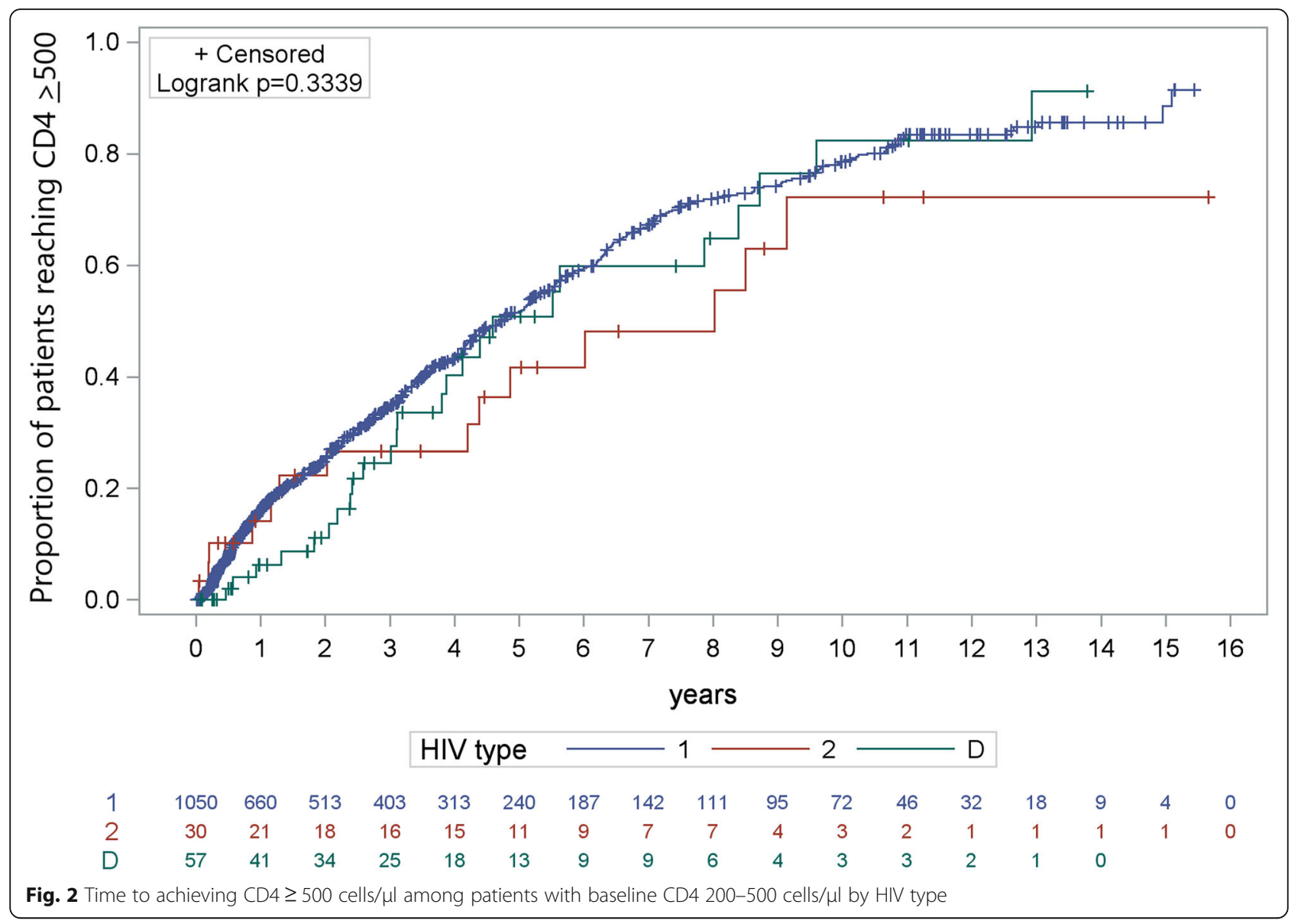

and/or already achieved by the time they initiate treatment, potentially contributing to the sub-optimal treatment responses that we observed. Our results for patients in the upper CD4 strata, in which HIV-type did not predict achievement of $\mathrm{CD} 4 \geq 500$ cells/ $\mu$ l during follow-up, are in line with this general hypothesis.

The findings in this study highlight the need for improved ART options for patients with HIV-2, a need which the HIV community is beginning to address. Recent publication of results from two trials of integrase inhibitor-based ART for HIV-2 [30, 31] suggest that both the quality of evidence and the efficacy of ART regimens will improve over time. However, HIV-2's geographic restriction to mostly low-resource settings in West Africa means that improved evidence, better treatment options, and updated guidelines are only part of the challenge of improving responses to HIV-2 treatment. Implementation of new treatment options in these settings will also need to include efforts to ensure that recommended ART options are available, prescribed correctly, and monitored over time.

Key strengths of this study included the large, wellcharacterized cohort and the length of follow-up. These data contribute to a better understanding of long-term responses to treatment among HIV-2 patients, support early ART initiation for all HIV types, and highlight the need for improved treatment options and guidelines for patinets with HIV-2. Limitations included the lack of reliable data describing patient treatment regimens and the lack of data characterizing responses to treatment, including routine viral load results and descriptions of patient outcomes. Limited availability of HIV-D patient samples for retesting was also a limitation, as studies suggest that it can be challenging to differentiate HIV-D patients from patients with HIV-1 (or HIV-2) monoinfection [32, 33]. The composition of the RETRO-CI database, which was maintained as part of routine laboratory testing, was also a limitation. It did not include variables that may have provided context to the data (such as laboratory methods). Finally, the study period was a limitation, as the early part of this period was one during which clinicians in Côte d'Ivoire prescribed nonrecommended ART regimens in hopes of improving responses to treatment. This has been noted in prior studies in Côte d'Ivoire [34] and implicated as a cause of poor responses to treatment among HIV-2 patients [35]. 


\section{Conclusions}

HIV-1 patients with low baseline CD4 counts in Côte d'Ivoire were more likely to achieve CD4 recovery during long-term follow-up than those with HIV-2. These findings likely reflect limited efforts to develop, optimize, and perscribe ART regimens specifically for HIV-2 and underscore the need for improved options. While the burden of HIV-2 is relatively small, it nevertheless contributes to HIV epidemics in many West African countries and must be treated effectively alongside HIV-1 in order for those countries to reach epidemic control.

\section{Abbreviations \\ ART: Antiretroviral therapy; CDC: Centers for Disease Control and Prevention; Cl: Confidence intervals; DAl: UNAIDS Drug Access Initiative; HIV-D: Dually reactive with HIV-1 and HIV-2; INSTI: Integrase strand transfer inhibitor; IQR: Interquartile ranges; KM: Kaplan-Meier; NNRTI: Non-nucleoside reverse transcriptase inhibitor; NRTI: Nucleoside reverse transcriptase inhibitor; PI: Protease inhibitor; USAC: Unité de Soins Ambulatoire et de Conseil; UTH: Treichville University Hospital}

\section{Acknowledgments}

The authors thank the RETRO-CI laboratory staff for their contributions to the study.

\section{Authorship disclaimer}

The findings and conclusions in this report are those of the authors and do not necessarily represent the official position of the funding agencies.

\section{Authors' contributions}

$\mathrm{KD}, \mathrm{JN}, J \mathrm{H}, \mathrm{KD}, \mathrm{GO}$ and $\mathrm{CA}$ designed and directed the project, GT, NK, MA contributed to data collection, PM, ER, and GZ conducted the analyses, PM drafted the manuscript and all authors read and approved the final version.

\section{Funding}

The RETRO-CI project and the authors of this manuscript were supported by the President's Emergency Plan for AIDS Relief (PEPFAR) through the Centers for Disease Control and Prevention (CDC). There was no specific funding allocated by PEPFAR or CDC in data collection, study design, data anlaysis, or writing.

\section{Availability of data and materials}

Data are owned by the Côte d'Ivoire Ministry of Health and may be requested by qualified researchers.

\section{Ethics approval and consent to participate}

This study was approved by the Ivorian Ethics Review Committee as well as the Office of the Associate Director for Science of the U.S Centers for Disease Control and Prevention (CDC). Patient consent was not required as only anonomyzed, routinely collected data were analyzed.

\section{Consent for publication}

Not Applicable.

\section{Competing interests}

The authors declare that they have no competing interests.

\footnotetext{
Author details

'Division of Global HIV and Tuberculosis, Centers for Disease Control and Prevention, 1600 Clifton Rd., Atlanta, GA, USA. ${ }^{2}$ Division of Global HIV and Tuberculosis, Centers for Disease Control and Prevention, Abidjan, Côte d'Ivoire. ${ }^{3}$ Division of Global HIV and Tuberculosis, Centers for Disease Control and Prevention, Pretoria, South Africa. ${ }^{4}$ Division of Global HIV and Tuberculosis, Centers for Disease Control and Prevention, Nairobi, Kenya. ${ }^{5}$ Africa Centres for Disease Control and Prevention, Addis Ababa, Ethiopia.
}

Received: 6 November 2019 Accepted: 27 February 2020

Published online: 12 March 2020

\section{References}

1. Clavel F, Guetard D, Brun-Vezinet F, Chamaret S, Rey MA, et al. Isolation of a new human retrovirus from west African patients with AIDS. Science. 1986; 233(4761):343-6.

2. Marlink R, Kanki P, Thior I, Travers K, Eisen G, et al. Reduced rate of disease development after HIV-2 infection as compared to HIV-1. Science. 1994; 265(5178):1587-90.

3. Jaffar S, Wilkins A, Ngom PT, Sabally S, Corrah T, et al. Rate of decline of percentage CD4+ cells is faster in HIV-1 than in HIV-2 infection. J Acquir Immune Defic Syndr Hum Retrovirol. 1997;16(5):327-32.

4. MacNeil A, Sarr AD, Sankale JL, Meloni ST, Mboup S, et al. Direct evidence of lower viral replication rates in vivo in human immunodeficiency virus type 2 (HIV-2) infection than in HIV-1 infection. J Virol. 2007:81(10):5325-30.

5. Berry N, Ariyoshi K, Jaffar S, Sabally S, Corrah T, et al. Low peripheral blood viral HIV-2 RNA in individuals with high CD4 percentage differentiates HIV-2 from HIV-1 infection. J Hum Virol. 1998;1(7):457-68.

6. Esbjornsson J, Mansson F, Kvist A, da Silva ZJ, Andersson S, et al. Long-term follow-up of HIV-2-related AIDS and mortality in Guinea-Bissau: a prospective open cohort study. Lancet HIV. 2019:6(1):e25-e31.

7. De Cock KM, Odehouri K, Colebunders RL, Adjorlolo G, Lafontaine MF, et al. A comparison of HIV-1 and HIV-2 infections in hospitalized patients in Abidjan, Cote d'Ivoire. AIDS. 1990;4(5):443-8

8. WHO. Consolidated guidelines on the use of antiretroviral drugs for treating and preventing HIV infection. Recommendations for a public health approach. Geneva: W.H. Organization; 2013.

9. WHO. Antiretroviral therapy for HIV infection in adults and adolescents. Geneva: World Health Organization; 2010.

10. Witvrouw M, Pannecouque C, Switzer WM, Folks TM, De Clercq E, et al. Susceptibility of HIV-2, SIV and SHIV to various anti-HIV-1 compounds: implications for treatment and postexposure prophylaxis. Antivir Ther. 2004; 9(1):57-65.

11. Desbois D, Roquebert B, Peytavin G, Damond F, Collin G, et al. In vitro phenotypic susceptibility of human immunodeficiency virus type 2 clinical isolates to protease inhibitors. Antimicrob Agents Chemother. 2008:52(4): 1545-8.

12. Raugi DN, Smith RA, Gottlieb GS, H.I.V.S.G. University of Washington-Dakar. Four amino acid changes in HIV-2 protease confer class-wide sensitivity to protease inhibitors. J Virol. 2016:90(2):1062-9.

13. Gottlieb GS, Raugi DN, Smith RA. 90-90-90 for HIV-2? Ending the HIV-2 epidemic by enhancing care and clinical management of patients infected with HIV-2. Lancet HIV. 2018;5(7):e390-9.

14. Requena S, Lozano AB, Caballero E, Garcia F, Nieto MC, et al. Clinical experience with integrase inhibitors in HIV-2-infected individuals in Spain. J Antimicrob Chemother. 2019;74(5):1357-62.

15. Le Hingrat Q, Collin G, Le M, Peytavin G, Visseaux B, et al. A new mechanism of resistance of HIV-2 to integrase inhibitors: a 5 amino-acids insertion in the integrase C-terminal domain. Clin Infect Dis. 2018.

16. Balestre E, Ekouevi DK, Tchounga B, Eholie SP, Messou E, et al. Immunologic response in treatment-naive HIV-2-infected patients: the leDEA West Africa cohort. J Int AIDS Soc. 2016;19(1):20044.

17. Ekouevi DK, Tchounga BK, Coffie PA, Tegbe J, Anderson AM, et al. Antiretroviral therapy response among HIV-2 infected patients: a systematic review. BMC Infect Dis. 2014:14:461.

18. Adje-Toure CA, Cheingsong R, Garcia-Lerma JG, Eholie S, Borget MY, et al. Antiretroviral therapy in HIV-2-infected patients: changes in plasma viral load, CD4+ cell counts, and drug resistance profiles of patients treated in Abidjan, Cote d'Ivoire. AIDS. 2003;17(Suppl 3):S49-54

19. Matheron S, Damond F, Benard A, Taieb A, Campa P, et al. CD4 cell recovery in treated HIV-2-infected adults is lower than expected: results from the French ANRS CO5 HIV-2 cohort. AIDS. 2006:20(3):459-62.

20. Wittkop L, Arsandaux J, Trevino A, Schim van der Loeff M, Anderson J, et al. CD4 cell count response to first-line combination ART in HIV-2+ patients compared with HIV-1+ patients: a multinational, multicohort European study. J Antimicrob Chemother. 2017:72(10):2869-78.

21. van der Ende ME, Prins JM, Brinkman K, Keuter M, Veenstra J, et al. Clinical, immunological and virological response to different antiretroviral regimens in a cohort of HIV-2-infected patients. AIDS. 2003;17(Suppl 3):S55-61. 
22. Benard A, Damond F, Campa P, Peytavin G, Descamps D, et al. Good response to lopinavir/ritonavir-containing antiretroviral regimens in antiretroviral-naive HIV-2-infected patients. AIDS. 2009;23(9):1171-3.

23. Jallow S, Alabi A, Sarge-Njie R, Peterson K, Whittle H, et al. Virological response to highly active antiretroviral therapy in patients infected with human immunodeficiency virus type 2 (HIV-2) and in patients dually infected with HIV-1 and HIV-2 in the Gambia and emergence of drugresistant variants. J Clin Microbiol. 2009;47(7):2200-8.

24. Toure S, Kouadio B, Seyler C, Traore M, Dakoury-Dogbo N, et al. Rapid scaling-up of antiretroviral therapy in 10,000 adults in Cote d'Ivoire: 2-year outcomes and determinants. AIDS. 2008;22(7):873-82.

25. Djomand G, Roels T, Ellerbrock T, Hanson D, Diomande F, et al. Virologic and immunologic outcomes and programmatic challenges of an antiretroviral treatment pilot project in Abidjan, Cote d'Ivoire. AIDS. 2003; 17(Suppl 3):S5-15.

26. Opportunistic Infections Project Team of the Collaboration of Observational, H.I.V.E.R.i.E.I.E., Young J, Psichogiou M, Meyer L, Ayayi S, et al. CD4 cell count and the risk of AIDS or death in HIV-Infected adults on combination antiretroviral therapy with a suppressed viral load: a longitudinal cohort study from COHERE. PLoS Med. 2012;9(3):e1001194.

27. Gras $L$, Kesselring AM, Griffin JT, van Sighem Al, Fraser C, et al. CD4 cell counts of 800 cells $/ \mathrm{mm} 3$ or greater after 7 years of highly active antiretroviral therapy are feasible in most patients starting with 350 cells/ mm3 or greater. J Acquir Immune Defic Syndr. 2007;45(2):183-92.

28. Moore RD, Keruly JC. CD4+ cell count 6 years after commencement of highly active antiretroviral therapy in persons with sustained virologic suppression. Clin Infect Dis. 2007;44(3):441-6.

29. Smith CJ, Sabin CA, Youle MS, Kinloch-de Loes S, Lampe FC, et al. Factors influencing increases in CD4 cell counts of HIV-positive persons receiving long-term highly active antiretroviral therapy. J Infect Dis. 2004;190(10): 1860-8.

30. Matheron S, Descamps D, Gallien S, Besseghir A, Sellier P, et al. First line raltegravir/emtricitabine/tenofovir combination in HIV-2 infection: phase 2 non-comparative trial (ANRS 159 HIV-2). Clin Infect Dis. 2018.

31. Ba S, Raugi DN, Smith RA, Sall F, Faye K, et al. A trial of a single tablet regimen of Elvitegravir, Cobicistat, Emtricitabine, and Tenofovir Disoproxil Fumarate for the initial treatment of HIV-2 infection in a resource-limited setting: 48 week results from Senegal, West Africa. Clin Infect Dis. 2018.

32. Tchounga BK, Inwoley A, Coffie PA, Minta D, Messou E, et al. Re-testing and misclassification of HIV-2 and HIV-1\&2 dually reactive patients among the HIV-2 cohort of the west African database to evaluate AIDS collaboration. J Int AIDS Soc. 2014;17:19064.

33. Peeters M, Fransen K, Gershy-Damet GM, Willems B, Koffi K, et al. Effect of methodology on detection of HIV-1/HIV-2 dual infections in Cote d'Ivoire. J Virol Methods. 1994;48(1):23-30.

34. Auld AF, Ekra KA, Shiraishi RW, Tuho MZ, Kouakou JS, et al. Temporal trends in treatment outcomes for HIV-1 and HIV-2-infected adults enrolled in Cote d'Ivoire's national antiretroviral therapy program. PLoS One. 2014;9(5): e98183.

35. Drylewicz J, Eholie S, Maiga M, Zannou DM, Sow PS, et al. First-year lymphocyte $T C D 4+$ response to antiretroviral therapy according to the HIV type in the leDEA West Africa collaboration. AIDS. 2010;24(7):1043-50.

\section{Publisher's Note}

Springer Nature remains neutral with regard to jurisdictional claims in published maps and institutional affiliations.

Ready to submit your research? Choose BMC and benefit from:

- fast, convenient online submission

- thorough peer review by experienced researchers in your field

- rapid publication on acceptance

- support for research data, including large and complex data types

- gold Open Access which fosters wider collaboration and increased citations

- maximum visibility for your research: over $100 \mathrm{M}$ website views per year

At BMC, research is always in progress.

Learn more biomedcentral.com/submissions 